\title{
A REVISÃO CRIMINAL COMO INSTRUMENTO DE EXECUÇÃO DAS SENTENÇAS DOS TRIBUNAIS INTERNACIONAIS DE DIREITOS HUMANOS: O CENÁRIO BRASILEIRO EM COMPARAÇÃO COM A DISCUSSÃO ITALIANA NO CASO DRASSICH
}

\section{CRIMINAL REVISION AS AN INSTRUMENT FOR THE ENFORCEMENT OF INTERNATIONAL HUMAN RIGHTS COURTS' JUDGMENTS: THE BRAZILIAN SCENARIO COMPARED WITH THE ITALIAN DEBATE ON DRASSICH CASE}

\author{
Vinicius Gomes de Vasconcellos \\ Universidade de São Paulo (USP) - (São Paulo, SP, Brasil) \\ Bruna Capparelli \\ Alma Mater Studiorum - Università di Bologna (Itália)
}

Recebimento: 28 set. 2016

Aceitação: 4 maio 2017

\begin{abstract}
Como citar este artigo / How to cite this article (informe a data atual de acesso / inform the current date of access):
VASCONCELLOS, Vinicius Gomes de; CAPPARELLI, Bruna. A revisão criminal como instrumento de execução das sentenças dos tribunais internacionais de direitos humanos: o cenário brasileiro em comparação com a discussão italiana no caso Drassich. Revista da Faculdade de Direito UFPR, Curitiba, PR, Brasil, v. 62, n. 2, p. 25 - 51, maio/ago. 2017. ISSN 2236-7284. Disponível em: <http://revistas.ufpr.br/direito/article/view/48670>. Acesso em: 28 ago. 2017. DOI: http://dx.doi.org/10.5380/rfdufpr.v62i2.48670.
\end{abstract}

\section{RESUMO}

A partir de revisão bibliográfica e estudo comparado de caso italiano, este artigo pretende analisar a efetividade das decisões de tribunais internacionais de direitos humanos no âmbito interno do Estadoparte condenado por violação à norma convencional relacionada ao devido processo penal. Contudo, em razão da inexistência de força coercitiva das decisões internacionais em relação aos ordenamentos dos Estados-parte, o cumprimento e o respeito às normas convencionais e à jurisprudência das cortes internacionais dependem fundamentalmente da ação dos próprios Estados, internalizando tais ditames a partir dos seus respectivos regramentos normativos. Diante disso, há que se questionar a existência e a necessidade de mecanismos jurídicos que possibilitem a efetividade dos julgados dos tribunais internacionais. Trata-se de tema pouco explorado na doutrina pátria, além de não expressamente regulado pela legislação nacional. Assim, a partir do estudo exemplificativo de um caso italiano emblemático, propor-se-á a interpretação extensiva das hipóteses de revisão criminal do Código de Processo Penal brasileiro, para autorizar a reabertura do processo penal e a relativização da coisa julgada condenatória interna em razão da violação de direitos do acusado reconhecidos convencionalmente. Por fim, será apresentada proposta de reforma legislativa, para introduzir previsão expressa da "revisão criminal convencional".

\section{PALAVRAS-CHAVE}

Processo penal. Revisão criminal. Crise do trânsito em julgado. Tribunais internacionais. Processo penal iníquo. 


\begin{abstract}
Grounded on a bibliographic review and a comparative study of an Italian case, this article aims at analyzing the effectiveness of international human rights courts' decisions in the internal framework of the State party convicted of violation of conventional rules related to the due criminal process. However, due to the lack of coercive force of international decisions in relation to the internal law of the State parties, compliance with the conventional norms and the jurisprudence of the international courts depends fundamentally on the action of the states themselves, internalizing these dictates considering their respective internal regulations. In view of this, it is necessary to question the existence and necessity of legal mechanisms that allow effectiveness to the judgments of the international courts. This theme is rarely explored by national doctrine, and it is not expressly regulated by national legislation. Thus, from the illustrative study of an emblematic Italian case, an extensive interpretation of the hypotheses of criminal revision provided for in the Brazilian Criminal Procedure Code, in order to allow the reopening of criminal proceedings and the relativization of internal res iudicata, due to violations of conventionally recognized accused's human rights. Finally, the article will expound a legislative reform proposal, to introduce an explicit provision for "conventional criminal revision”.
\end{abstract}

\title{
KEYWORDS
}

Criminal procedure. Criminal revision. Res iudicata crisis. International courts. Unfair criminal process.

\section{INTRODUÇÃO}

No debate contemporâneo do direito processual penal, um tema de crescente relevância é a proteção internacional dos direitos humanos. Diante do paulatino fortalecimento dos sistemas regionais, as cortes de direitos humanos passam a direcionar seus esforços para a busca de conformidade convencional, dos ordenamentos internos, às previsões dos diplomas internacionais, como a Convenção Americana de Direitos Humanos e a Convenção Europeia de Direitos Humanos. Nesse sentido, o processo penal e a justiça criminal de um modo amplo são objetos primordiais dessa tutela, visto que abrangem um âmbito de extrema coercibilidade do poder estatal nos direitos de seus cidadãos.

Contudo, em razão da inexistência de força coercitiva das decisões internacionais em relação aos ordenamentos dos Estados-parte, o cumprimento e o respeito às normas convencionais e à jurisprudência das cortes dependem fundamentalmente da ação dos próprios Estados, internalizando tais ditames a partir dos seus respectivos regramentos normativos. Diante disso, há que se questionar a existência e a necessidade de mecanismos jurídicos que possibilitem a efetividade dos julgados dos tribunais internacionais.

Embora ainda se mostre necessária a consolidação do respeito à jurisprudência das cortes internacionais de direitos humanos de um modo amplo (GIACOMOLLI, 2014, p. 32-36; CHOUKR, 2016, p. 282-283), este artigo pretende enfocar os casos em que o respectivo Estado-parte tenha sido 
parte no processo e reste condenado por violações a dispositivos convencionais, especialmente em casos de desrespeito a direitos humanos que limitem a persecução criminal, a partir das regras do devido processo penal. O problema que se almeja discutir é: Como assegurar a efetividade das decisões das cortes internacionais em casos de violações a regras convencionais do devido processo penal que reconheçam a injustiça de uma condenação criminal proferida em âmbito interno e transitada em julgado?

Para tanto, o texto será dividido em três tópicos. Primeiramente, serão expostos os elementos essenciais do estudo do status normativo dos tratados internacionais de direitos humanos à análise em âmbito do direito processual penal, com o fim de assentar as premissas ao exame do impacto das decisões das cortes internacionais ao caso julgado na esfera interna. Posteriormente, será analisado o exemplo italiano no caso Drassich, o qual apresenta pertinentes complexidades relacionadas à coisa julgada interna e sua relação com os precedentes das cortes internacionais de direitos humanos. Por fim, deslocando-se tais contribuições ao cenário brasileiro, estudar-se-á a compatibilidade do ordenamento pátrio com um sistema convencional de proteção de direitos humanos, essencialmente focando-se a viabilidade da reabertura de casos já transitados em julgado internamente nas hipóteses de reconhecimento, por corte internacional, de violação.

\section{BREVES PREMISSAS SOBRE O STATUS NORMATIVO DOS TRATADOS INTERNACIONAIS DE DIREITOS HUMANOS E SEUS REFLEXOS AO PROCESSO PENAL BRASILEIRO}

Os fenômenos da internacionalização dos direitos humanos e da tutela multinível dos direitos fundamentais ${ }^{1}$ implicam impactos diretos no direito processual penal, aportando consequências relevantes à sua estruturação central (GIACOMOLLI, 2014, p. 12-22). A preocupação por uma leitura convencional dos dispositivos do Código de Processo Penal (CPP) brasileiro de 1941 é crescente e tem refletido em decisões dos tribunais brasileiros, ou seja, o Judiciário pátrio começa a valorizar a Convenção Americana de Direitos Humanos (CADH) e o seu impacto no ordenamento nacional, mas a partir de uma interpretação "brasileira” do seu conteúdo. Contudo, por outro lado, ainda é incipiente

\footnotetext{
${ }^{1}$ Sobre isso, amplamente, KOSTORIS (2014), segundo o qual dita tutela “é o complexo de institutos de várias matrizes, normativas e jurisprudenciais, por meio das quais se articulam as várias competências e relações entre jurisdições nacionais e supranacionais diante das quais é possível prevalecer a tutela dos direitos fundamentais” (p. 64, tradução nossa).
} 
a utilização de decisões proferidas pela Corte Interamericana (Corte IDH), como intérprete legítima das previsões convencionais.

Portanto, atualmente parece haver uma concretização parcial da normativa convencional no campo jurídico brasileiro, visto que começa a se generalizar a referência a dispositivos da CADH, porém interpretados a partir da visão dos aplicadores nacionais, relegando-se a um segundo plano a jurisprudência emanada pela Corte IDH. Diante disso, neste tópico será analisado o panorama dos tratados internacionais de direitos humanos e seus reflexos ao ordenamento pátrio, especialmente ao direito processual penal, tanto em relação ao status normativo de seus dispositivos, quanto no que diz respeito às consequências das decisões proferidas pelas cortes legitimadas à sua interpretação.

\subsection{O IMPACTO DOS DISPOSITIVOS DA CONVENÇÃO AMERICANA DE DIREITOS HUMANOS NO ORDENAMENTO BRASILEIRO}

$\mathrm{O} \S 2^{\circ}$ do art. $5^{\circ}$ da Constituição Federal de 1988 dispõe que "os direitos e garantias expressos nesta Constituição não excluem outros decorrentes do regime e dos princípios por ela adotados, ou dos tratados internacionais em que a República Federativa do Brasil seja parte”. Assim, o rol de direitos fundamentais elencados expressamente no texto constitucional não é taxativo, possibilitando-se o reconhecimento de direitos em igualdade de importância, a partir dos diplomas internacionais subscritos pelo País (RAMOS, 2014, p. 226)².

Inicialmente, em importante julgado, no Recurso Ordinário em Habeas Corpus número 79.785-7/RJ, de 29 de março de 2000, a partir de voto do relator ministro Sepúlveda Pertence, assentou-se posição pela prevalência da Constituição Federal (CF) sobre cláusulas de convenções internacionais. Conforme decidido pelo Supremo Tribunal Federal (STF), para que se desse eficácia à cláusula da $\mathrm{CADH}$ que reconhece o direito ao recurso ao condenado no processo penal, "não bastaria sequer lhe conceder o poder de aditar a Constituição [...] mais do que isso, seria necessário emprestar à norma convencional força ab-rogante da Constituição mesma, quando não dinamitadoras do seu sistema, o que não é de admitir”.

Em momento posterior a tal julgado paradigmático, por modificação ocasionada pela Emenda Constitucional número 45/2004, inseriu-se o $\S 3^{\circ}$ no mesmo dispositivo, determinando que “tratados e convenções internacionais sobre direitos humanos que forem aprovados, em cada Casa do Congresso Nacional, em dois turnos, por três quintos dos votos dos respectivos membros, serão

\footnotetext{
${ }^{2}$ Cumpre frisar que havia orientação jurisprudencial no STF, anterior à reforma de 2004, assentada no RE 80.004 de 1977, no sentido de que os tratados internacionais, ainda que regulassem matéria relativa aos direitos humanos, seriam equivalentes a lei ordinária federal, quando incorporados ao ordenamento interno (RAMOS, 2014, p. 274).
} 
equivalentes às emendas constitucionais”. Assim, foi previsto procedimento de recepção formal dos diplomas internacionais sobre direitos humanos, os quais precisam ser aprovados pelo Congresso Nacional com quórum qualificado, obtendo então status hierárquico normativo equivalente às normas constitucionais. Contudo, textos convencionais que ingressaram no ordenamento brasileiro anteriormente à emenda, como o Pacto Internacional sobre Direitos Civis e Políticos (PIDCP) e a $\mathrm{CADH}$, não respeitaram tal formalidade, inexistente à época.

Desse modo, o debate doutrinário não foi pacificado com a reforma constitucional de 2004, visto que o novo $\S 3^{\circ}$ do art. $5^{\circ}$ da CF foi objeto de inúmeras críticas, em razão de uma confusa regulação de dois sistemas distintos para recepção dos tratados internacionais sobre direitos humanos, caso respeitassem ou não a formalidade prevista no momento de sua aprovação (RAMOS, 2014, p. 278-279). Conforme Valerio Mazzuoli (2013, p. 41):

Não obstante ter tido o art. $5^{\circ}$, $\S 3^{\circ}$, da Constituição um aparente bom propósito, o certo é que se trata de um dispositivo incongruente. Se sua intenção foi colocar termo às controvérsias (doutrinárias e jurisprudenciais) sobre o nível hierárquico dos tratados de direitos humanos no Brasil, parece que tal desiderato não conseguiu chegar.

Em decisões posteriores, o STF analisou a possibilidade de prisão civil de depositário infiel. Trata-se de hipótese vedada pelo artigo $7^{\circ}$, número 7, da CADH, que determina: “Ninguém deve ser detido por dívidas. Este princípio não limita os mandados de autoridade judiciária competente expedidos em virtude de inadimplemento de obrigação alimentar”. Assim, firmou-se a tese de que os tratados internacionais de direitos humanos não aprovados conforme o quórum qualificado previsto no art. $5^{\circ}$, $\S 3^{\circ}$, da $\mathrm{CF}$, possuem nível hierárquico de supralegalidade, ou seja, acima das leis infraconstitucionais, mas abaixo da Constituição Federal (BARROSO, 2013, p. 171-180; MAUÉS, 2013, p. 228-229)33. Diante disso, reconheceu-se a inaplicabilidade da autorização de prisão do depositário infiel prevista no Código Civil brasileiro, o qual, como norma infralegal, sairia prejudicado no conflito com a CADH, de caráter supralegal (MENDES, 2013, p. 214-233).

Portanto, o STF sustenta atualmente, majoritariamente, a posição da supralegalidade dos tratados internacionais de direitos humanos não aprovados com atenção ao quórum previsto no $\S 3^{\circ}$ do art. $5^{\circ}$ da CF, de modo a autorizar a restrição às previsões convencionais em situações de conflito com a normativa constitucional interna (CAMPOS, 2014, p. 78; PEREIRA, 2013a, p. 101). Ainda assim há forte crítica doutrinária direcionada contra esse posicionamento.

\footnotetext{
${ }^{3}$ Nesse sentido, os casos paradigmáticos foram: Recurso Extraordinário 466.343/SP, Tribunal Pleno, Rel. Min. Cezar Peluso, j. 03/12/2008; Habeas Corpus 87.585/TO, Tribunal Pleno, Rel. Min. Marco Aurélio, j. 03/12/2008; e Recurso Extraordinário 349.703/RS, Tribunal Pleno, Rel. p/ Acórdão Min. Gilmar Mendes, j. 03/12/2008.
} 
Em oposição a tal visão jurisprudencial dominante, há quem sustente a natureza constitucional dos ditames convencionais sobre direitos humanos já a partir do regramento previsto inicialmente, na Constituição brasileira, no § $2^{\circ}$ do artigo $5^{\circ}$ (CUNHA; BALUTA, 2000, p. 51; MAZZUOLI, 2013, p. 37, 58). Ademais, diante da confusa redação do $\S 3^{\circ}$ do art. $5^{\circ}$ da CF, Flávia Piovesan afirma que todos os tratados de direitos humanos, por força do $\S 2^{\circ}$ do referido dispositivo, são materialmente constitucionais, mesmo sem terem obtido o quórum qualificado previsto pela Emenda Constitucional n. 45/2004, pois “a leitura sistemática dos dispositivos aponta que o quórum qualificado está tão somente a reforçar tal natureza constitucional, ao adicionar lastro formalmente constitucional aos tratados ratificados” (PIOVESAN, 2005, p. 9) ${ }^{4}$. Em resumo, trata-se de posição amplamente endossada doutrinariamente, que atesta a materialidade constitucional, ainda que não atendida a formalidade introduzida no $\S 3^{\circ}$ do art. $5^{\circ}$ da CF: "os tratados de direitos humanos possuem natureza constitucional” (CEIA, 2013, p. 144; RAMOS, 2014, p. 281).

Esse é, em linhas gerais, o panorama em relação ao status normativo dos tratados internacionais sobre direitos humanos no ordenamento brasileiro, tema que, embora ainda não consolidado de modo generalizado nos tribunais pátrios, tem sido objeto de atenção da doutrina nacional. Por outro lado, questão ainda carente de consolidação jurisprudencial e pouco explorada cientificamente (especialmente em âmbito processual penal) é a efetividade das decisões proferidas pelos tribunais internacionais de direitos humanos, como a Corte IDH. Ou seja, além da realização de um “controle de convencionalidade difuso" pelos juízes brasileiros (que, assim, dão a sua interpretação aos ditames da $\mathrm{CADH}$ ), impõe-se o fortalecimento do "controle de convencionalidade concentrado”, realizado pela Corte IDH no âmbito de incidência da CADH.

Conforme Rangel Hernández (2011, p. 180, tradução nossa), o Estado-parte “está obrigado a cumprir não somente as disposições do pacto que voluntariamente assinou, mas também a se pautar pela jurisprudência que emita o órgão intérprete de tal normal internacional e, especialmente, a executar as sentenças condenatórias proferidas contra si”. Ou seja, há a consolidação de um dever de respeito aos ditames convencionais não somente aos poderes Executivo ou Legislativo, mas de igual modo ao Judiciário (CAPPARELLI, 2016, p. 246, tradução nossa).

Ao firmar a CADH, o Estado-parte assume a obrigação de respeitar os dispositivos convencionais nela previstos, o que inclui a submissão à competência da Corte IDH. Conforme o art. 62 do referido diploma,

\footnotetext{
${ }^{4}$ Assim também em PIOVESAN, 2009, p. 72. De modo semelhante, na doutrina processual penal: BADARÓ, 2014, p. 4-5; VASCONCELLOS, 2014, p. 229.
} 
Todo Estado-parte pode, no momento do depósito do seu instrumento de ratificação desta Convenção ou de adesão a ela, ou em qualquer momento posterior, declarar que reconhece como obrigatória, de pleno direito e sem convenção especial, a competência da Corte em todos os casos relativos à interpretação ou aplicação desta Convenção.

Em atenção a tal procedimento, o Brasil reconheceu expressamente a jurisdição da Corte IDH em 1998, por meio da Mensagem Presidencial 1.070/98, que foi aprovada pelo Decreto Legislativo 89/98 (RAMOS, 2008, p. 452).

Assim, no sentido claramente determinado pelo preceito convencional, consagra-se uma obrigação internacional de respeito às decisões da Corte. Nesse sentido, “uma vez que o Estado-parte tenha reconhecido tal competência, estará, então, vinculado às decisões que a Corte proferir, devendo acatá-las e tomar as providências necessárias no plano interno para o seu cabal cumprimento” (PEREIRA, 2013a, p. 96). Contudo, na prática, a força de tais precedentes tem sido esvaziada no campo jurídico brasileiro, especialmente em razão da ausência de mecanismos especificamente previstos para a execução interna das decisões internacionais (PEREIRA, 2013b, p. 316).

\subsection{AS DECISÕES DA CORTE INTERAMERICANA DE DIREITOS HUMANOS EM CASOS CONCRETOS CONTRA UM ESTADO-PARTE E SUA EXECUÇÃO INTERNA}

Conforme exposto, os países signatários da CADH que reconhecerem a competência da Corte IDH, em conformidade com o seu art. 62, submetem-se à competência do referido órgão internacional, consolidando um dever de execução interna do julgado. Segundo Mac-Gregor e Möller (2012, p. 145), considerando o cenário mexicano de submissão à Corte IDH, as sentenças do referido órgão, quando o Estado-parte tenha sido parte no processo, “constituem coisa julgada e são obrigatórias em seus termos”.

Nesse sentido, diante da ausência de força executiva direta das sentenças das cortes internacionais - o que é a regra aceita majoritariamente pela doutrina (KOSTORIS, 2009, p. 2.523) -, mostra-se necessário o estabelecimento de mecanismos internos para o cumprimento das obrigações determinadas na responsabilização internacional. Como firmado por Carvalho Ramos (2008, p. 459), “a execução das sentenças da Corte depende da normatividade interna”, de modo que “cabe a cada Estado escolher a melhor forma, de acordo com o seu Direito, de executar os comandos da Corte Interamericana de Direitos Humanos”.

Nos termos do art. 68.1 da CADH, "os Estados-partes na Convenção comprometem-se a cumprir a decisão da Corte em todo caso em que forem partes”. Embora o dever de submissão à 
competência da Corte seja claro, discutem-se os efeitos das sentenças proferidas por tribunais internacionais.

Conforme a posição majoritária,

[...] as sentenças da Corte Interamericana possuem em geral o caráter obrigatório, mas não executório, pois apesar de não existir um mecanismo internacional que force os Estados a cumprirem coercitivamente a decisão, eles são responsabilizados internacionalmente pelo fato de terem se comprometido executar as decisões quando ratificaram a Convenção Americana (LEITE, 2008, p. 460).

Afirma-se que a Corte não possui poderes coercitivos diretos para obrigar o Estado a cumprir internamente as suas decisões, de modo que caberá à voluntariedade do Estado-parte a sua atenção (ANDRADE, 2006, p. 157).

Parte da doutrina afirma que as sentenças das cortes internacionais devem ser consideradas como “de aplicação e execução direta” no ordenamento interno (RANGEL HERNÁNDEZ, 2011, p. 180). Nesse sentido, em relação ao ordenamento brasileiro, tais sentenças deveriam ser consideradas títulos executivos judiciais, pois, segundo Resende (2013, p. 235), “exaradas por órgão judicial, cuja jurisdição a República Federativa do Brasil reconhece e se submete”.

Essa visão tem se consolidado em relação às condenações proferidas pela Corte IDH que determinam obrigações indenizatórias pecuniárias às vítimas de violações a direitos convencionalmente assegurados (RAMOS, 2008, p. 460-461). Nos casos em que o Brasil foi condenado, houve o pagamento da quantia por ação voluntária do governo, por meio de decreto do Executivo, como em Ximenes Lopes (6.185/07), Escher (7.158/10) e Garibaldi (7.307/10).

Contudo, nos casos em que a Corte IDH reconhece uma violação de um direito convencional relacionado às regras do devido processo penal e, assim, declara como ilegítima ${ }^{5}$ uma condenação criminal proferida pelo Estado-parte, a execução interna da sentença internacional se mostra mais complexa (CORAO, 2007, p. 150). Tendo em vista a regra da subsidiariedade das cortes internacionais de direitos humanos, que, em geral, somente podem atuar após o exaurimento de todos os meios impugnativos previstos no ordenamento interno do país, o caso penal já resta finalizado, com o estabelecimento da condenação definitiva transitada em julgado (CAIANIELLO, 2009, p. 1.465 et seq.; RESENDE, 2013, p. 229).

\footnotetext{
5 “Convencionalmente ilegítima” é a sentença em que um tribunal internacional de direitos humanos reconhece uma violação à norma convencional de natureza processual, relacionada às regras do devido processo penal; por outro lado, “convencionalmente injusta” é a decisão que viola normas convencionais de natureza material. Sobre isso, ver GERACI, 2012, p. 80.
} 
O problema fundamental aqui tratado, portanto, ocorrerá nos casos em que exista uma condenação transitada em julgado em âmbito interno no Estado-parte e haja o reconhecimento da existência de violação à previsão convencional, restando declarada a ilegitimidade da condenação por meio de sentença proferida por corte internacional de direitos humanos. Ou seja, trata-se de verificar o "grau de resistência da coisa julgada diante do impulso exercido pelas decisões” originárias de tribunais internacionais (CAPPARELLI, 2016, p. 242, tradução nossa).

Diante disso, parte da doutrina afirma que tal decisão teria natureza meramente declaratória, de modo a não implicar consequências necessárias ao ordenamento interno do Estado-parte (MONTESINOS PADILLA, 2016, p. 99; RUIZ MIGUEL, 2016, p. 378). Isso, contudo, tem sido questionado inclusive pela prática ocorrida no âmbito das decisões internacionais proferidas pelos tribunais. Por exemplo, em Tamayo vs. Perú, a Corte IDH determinou a soltura de preso, em razão de violação a preceito convencional no seu julgamento (RAMOS, 2008, p. 462). De modo semelhante, no caso Assanidzé vs. Geórgia, de 2004, o Tribunal Europeu dos Direitos Humanos (TEDH) determinou a colocação em liberdade do acusado, “em prazo mais rápido possível” (GERACI, 2012, p. 76).

Embora na maioria dos casos não haja a determinação de medida semelhante, é comum a declaração da ilegitimidade da condenação, o que deverá ser enfrentado pelo Estado-parte, adotando as medidas necessárias para a reparação da violação ocorrida. Segundo Geraci, a exigência de garantir a efetividade dos sistemas internacionais de direitos humanos pressupõe o pleno respeito às sentenças definitivas proferidas pelas cortes internacionais em face de violação cometida por Estado-parte, sob pena de “o próprio conceito de fair trail se esvaziar, tornando-se meramente ilusório" (GERACI, 2012, p. 68, tradução nossa).

Assim, especialmente nas hipóteses em que o imputado tenha sido responsabilizado criminalmente e esteja cumprindo uma pena, configura-se como medida imprescindível para o saneamento do vício a reabertura do processo anteriormente finalizado no âmbito interno do Estadoparte (KOSTORIS, 2009, p. 2.523 et seq.). Conforme assentado pelo Tribunal Europeu de Direitos Humanos em 2010, no caso Ogaristi vs. Itália,

\footnotetext{
[...] quando o Tribunal concluir que a condenação de um recorrente tenha sido pronunciada em um processo injusto, afirma-se que, em regra, a reparação mais adequada consiste em um novo juízo do imputado, promovido a partir de requerimento por sua iniciativa, em prazo razoável e com respeito às regras previstas no art. $6^{\circ}$ da Convenção Europeia de Direitos Humanos (STEFANO, 2011, p. 1).
}

Partindo-se da premissa de que pode ser necessária a reabertura do processo penal em que houve uma condenação transitada em julgada e considerada ilegítima por um tribunal internacional 
de direitos humanos, deve-se questionar acerca do meio adequado para sua solicitação, conforme o ordenamento interno do Estado-parte. Diante desse problema, nos próximos tópicos deste trabalho serão analisadas as possibilidades de impugnações para reabertura de caso, especialmente a revisão criminal, a partir do exemplo italiano e do cenário brasileiro atual.

\section{A REABERTURA DE CASO NO PROCESSO PENAL ITALIANO POR CONDENAÇÃO NO TRIBUNAL EUROPEU DE DIREITOS HUMANOS: O EXEMPLO DO CASO DRASSICH}

Assentadas as premissas em relação ao status normativo dos tratados internacionais de direitos humanos e à submissão dos Estados-partes à competência dos tribunais internacionais, elucidou-se o problema objeto deste estudo: diante do trânsito em julgado da condenação no âmbito interno, qual o instrumento legítimo para reabertura de processo penal em caso de reconhecimento de violação de norma convencional? Para analisar tal questão e propor direções à discussão brasileira, inicialmente será exposto o panorama italiano, em que houve debates doutrinários e jurisprudenciais sobre a matéria, o que propicia a indicação de possíveis pautas para guiar o estudo ${ }^{6}$.

Embora anteriormente tenha adotado posição contrária (na decisão n. 129, de 30 de abril de 2008) ${ }^{7}$, a Corte Constitucional italiana analisou esse tema e assentou sua visão de modo contundente na sentença n. 113, de 7 de abril de $2011^{8}$. Nesse julgado, declarou-se a ilegitimidade constitucional do art. 630 do Código de Processo Penal italiano, o qual regula as hipóteses de cabimento da revisão criminal, mas não prevê o caso de reabertura do processo, quando seja necessário, para conformação da resolução nacional a uma sentença definitiva do Tribunal Europeu de Direitos Humanos, nos termos do art. 46.1 da CEDH (STEFANO, 2011, p. 2). Na decisão determinou-se a seguinte ementa:

\footnotetext{
${ }^{6}$ Para um estudo crítico sobre a ideia do trânsito em julgado penal, ver: CAPPARELLI; VASCONCELLOS, 2018, no prelo.

${ }^{7}$ Disponível em: <https://goo.gl/3U1Bap>. Acesso em: 14 set. 2016.

${ }^{8}$ Sobre o recente affaire Contrada, no qual a Corte Europeia reconheceu a violação do artigo 7 da CEDU por parte da Itália, visto que no momento em que os fatos penais foram contestados ao réu, a norma penal aplicada no processo interno não era suficientemente clara e previsível, ver: Tribunal Europeu de Direitos Humanos, 14 de abril de 2015, Contrada contra Italia (n. 3). Especificamente, tratava-se de uma hipótese de concurso em associação mafiosa, imputada ao recorrente por fatos cometidos entre 1979 e 1988 - ou seja, em uma época antecedente àquela em que, segundo o tribunal europeu, o delito em questão tenha sido reconhecido oficialmente pela jurisprudência italiana -: dita infração, de fato, seria o resultado de uma evolução jurisprudencial iniciada no final dos anos oitenta e consolidada somente em 1994 com a notória sentença Demitry. Porém, no caso em exame, o recorrente, vitorioso em Estrasburgo na primavera europeia de 2015, já tinha terminado de cumprir toda a sua pena em outubro de 2012. Quid iuris: quando a pena infligida, julgada convencionalmente ilegítima pela corte, tenha sido integralmente espiada pelo réu, inexiste in rerum natura a possibilidade de uma satisfatória restitutio in integrum do recorrente?
} 
Processo penal - casos de revisão - Renovação do processo em razão de a sentença ou o decreto penal condenatório esteja em conflito com uma sentença definitiva do Tribunal Europeu de Direitos Humanos que tenha determinado a injustiça do processo, diante da Convenção Europeia de Direitos Humanos - Dispositivo insuficiente - Ilegitimidade constitucional parcial do art. 630 do Código de Processo Penal ${ }^{9}$

Diante da inércia do Legislativo e a subsequente crise da res iudicata (CAPRIOLI, 2011, p. 3, 75-76), diversos casos foram julgados, partindo das premissas assentadas na sentença n. 113/2011, mas aprofundando a análise de aspectos problemáticos de sua realização prática. Nesse sentido, o caso Drassich apresenta contribuições relevantes ao debate, de modo que se impõe o seu estudo específico $^{10}$.

2.1 O CASO DRASSICH: RELATO DOS PONTOS DISCUTIDOS E DE SUA RELAÇÃO COM A EXECUÇÃO DAS SENTENÇAS DAS CORTES INTERNACIONAIS DE DIREITOS HUMANOS

Mais de uma vez submetida à atenção da Suprema corte, o notório caso processual objeto da sentença comentada pode ser assim sinteticamente recapitulado ${ }^{11}$. O imputado, acusado dos crimes de falso, abuso de ofício e corrupção, foi condenado, em primeiro grau, em concurso com outros, à pena de três anos de reclusão, em relação aos crimes de falso e a cinco episódios de corrupção por atos contrários aos deveres de ofício ex art. 319 do CP italiano. O julgamento de apelação, proposto tanto pelo imputado quanto pelo Ministério Público, foi concluído com um agravamento de pena, aumentada a três anos e oito meses de reclusão, após a investigação de outros episódios de corrupção.

A decisão de segundo grau, por sua vez, foi objeto de impugnação por parte do imputado, que invocava, entre outros, a intervinda prescrição - com base na disciplina contida no art. 157 do CP italiano até então vigente - pelo crime do art. 319 do CP italiano, em virtude das circunstâncias atenuantes reconhecidas na sentença.

Com a sentença de 2 de fevereiro de 2004, todavia, a Suprema Corte rejeitou o recurso, requalificando mais gravemente os fatos como corrupção, em atos judiciais ex art. 319-ter do CP italiano, ao considerar infundadas as alegações de mérito, com a não declaração de extinção da punibilidade do crime por prescrição.

\footnotetext{
${ }^{9}$ Disponível em: <https://goo.gl/J9y5Zj>. Acesso em: 14 set. 2016.

10 Sobre a discussão de conteúdo realizada no referido julgado, ver GLOECKNER, 2016, p. 191-193.

${ }^{11}$ Ver síntese do caso em CAPPARELLI, 2016, p. 263. Sobre o tema da atividade argumentativa das partes, amplamente, ver ORLANDI, 2010, p. 62 et seq.
} 
Seguiu-se o trânsito em julgado da sentença e o recurso do interessado à Corte de Estrasburgo (TEDH), a qual reconheceu nos fatos aqui sinteticamente relatados uma violação do art. 6 da Convenção Europeia dos Direitos Humanos (CEDU), não tendo sido o imputado "avisado sobre a possibilidade de uma requalificação da acusação contestada e, ainda menos, colocado na condição de discutir em contraditório o novo nomen iuris"12.

O tribunal supranacional determinou que, para a reparação da violação, dever-se-ia iniciar um novo processo ou, por pedido do interessado, reabrir o procedimento nacional.

Em ausência de remédios internos específicos, o recorrente pediu ao juiz de execução para declarar inexequível o título ex art. 670 do CPP italiano ${ }^{13}$, com base em alguns precedentes oferecidos pela jurisprudência da Corte di Cassazione ${ }^{14}$.

Ao decidir o recurso proposto contra a ordinanza ${ }^{15}$ do juiz da execução, a Corte di Cassazione aplicou, em interpretação extensiva, o art. 625-bis do CPP italiano ${ }^{16}$, anulando parcialmente a própria pronúncia de 2004 e celebrando novamente o julgamento, somente em relação ao motivo referido à prescrição, com contraditório preventivo sobre a correta qualificação jurídica dos fatos. Assim, foi proferida uma nova sentença, na qual se confirmou a correta qualificação jurídica ex art. 319-ter do CP italiano, com exclusão da extinção do crime.

Subsequentemente à nova pronúncia definitiva, a Corte Constitucional, com a citada sentença número 113 de 2011², introduziu uma especial hipótese de revisão, dependente do julgamento definitivo, por parte do Tribunal Europeu, de uma violação, que possibilite o requerimento da reabertura do processo. O condenado usufruiu, então, de tal direito, mas a corte d'appello competente declarou inadmissível o pedido de revisão.

Na impugnação contra a ordinanza de inadmissibilidade sustentou-se a ineficácia do recurso ex art. 625-bis do CPP italiano na aplicação extensiva feita pela corte de cassação, consideradas as

\footnotetext{
${ }^{12}$ Disponível em: <https://goo.gl/RbzsMF>. Acesso em: 14 set. 2016.

${ }^{13}$ No ordenamento italiano, o incidente de execução permite a verificação do título executivo com base no qual se iniciará, ou já foi iniciada, a execução penal da pena imposta com a sentença de condenação. Dito controle é operado pelo juiz da execução, ex officio ou por iniciativa da parte, tendendo a verificar se o título executivo é existente e eficaz. Para uma completa análise da disciplina ver CAPRIOLI; VICOLI, 2011, p. 263 et seq. Sobre o tema de requalificação jurídica dos fatos, ver QUATTROCOLO, 2010, p. 337 et seq.

${ }^{14}$ Em seu tempo, o problema da não exigibilidade do trânsito em julgado, contrastante com a Convenção Europeia, foi amplamente debatido na Itália. Entre as numerosas contribuições ver, por exemplo, UBERTIS, 2008, p. 99 et seq.

${ }^{15}$ Forma pela qual é denominada uma tipologia de decisão jurisdicional no âmbito de um processo penal, civil, administrativo ou constitucional. Normalmente destina-se a regulamentar o desenvolvimento do processo e deve necessariamente ser fundamentada pelo juiz que a pronunciou. Com específica referência ao processo penal italiano, a sua disciplina está nos artigos 125 et seq. do CPP.

16 Trata-se do recurso extraordinário em Cassazione e dito instituto, introduzido com a reforma de 2001, é um meio extraordinário de impugnação relativo à correção de tipos particulares de erro (material ou de fato), taxativamente indicados pela lei e presentes na sentença da Corte di Cassazione.

${ }^{17}$ Sobre isto ver, entre outros, UBERTIS, 2011, p. 1.542 et seq.
} 
características de tal procedimento em relação à restitutio in integrum como indicada na sentença de Estrasburgo (TEDH). A discussão in iure, na verdade, teria se realizado sem a participação pessoal do imputado, não garantida no juízo de legitimidade; o imputado, além disso, não teria tido a possibilidade de reorientar a própria estratégia defensiva e pedir novas provas, objetivo que, segundo o recorrente, seria a base da reabertura determinada na sentença da corte europeia.

Em linha com a exigência de perseguir esse objetivo, conforme o recorrente, seria, em realidade, a jurisprudência de legitimidade, que, depois do prosseguimento judiciário do caso Drassich, diversamente reconheceu a nulidade das sentenças, de primeiro e de segundo grau, que tinham efetuado uma requalificação do fato ex art. 521, parágrafo $1^{\circ}$, ou 597 do CPP italiano, em ausência de contraditório prévio no mesmo grau de julgamento.

Esse foi o panorama da questão sobre a qual foi chamada a pronunciar-se a Corte de Cassação italiana.

Trata-se portanto de verificar, em primeiro lugar, a adequação da fórmula de renovação/reabertura do processo, adotada neste caso para remover as consequências da violação convencional, assim como determinada pela Corte de Estrasburgo ${ }^{18}$. Em segundo lugar, é necessário analisar se, em um caso como esse, existe atualmente um remédio capaz de subtrair à sentença irrevogável a força executiva que o art. 650 do CPP italiano lhe atribuiu em relação à efetiva consistência das violações declaradas pelo TEDH ${ }^{19}$.

\subsection{O TRÂNSITO EM JULGADO NACIONAL E A RESTITUTIO IN INTEGRUM}

Ao analisar a decisão, a base da motivação da Corte foi constituída pela distinção entre a hipótese de requalificação jurídica operada durante o juízo recursal de legitimidade e aquela efetuada no julgamento de mérito em primeiro grau ${ }^{20}$. A esse propósito o recorrente lamentava, como dito, que o remédio adotado com o uso do instrumento ex art. 625-bis do CPP italiano (uma espécie de recurso de cassação extraordinário após o trânsito em julgado da condenação ${ }^{21}$ não poderia considerar-se

\footnotetext{
${ }^{18}$ Para um estudo dogmático sobre a teoria do prejuízo efetivo, ver CAIANIELLO, 2012.

${ }^{19}$ Em argumento, amplamente, CAPRIOLI, 2013, p. 263 et seq.

${ }^{20}$ Ver CAIANIELLO, 2007, p. 167 et seq.

${ }^{21}$ Sobre isto, analiticamente, ver CAIANIELLO, 2009, p. 1.465 et seq.
} 
adequado ao fim de restaurar o direito violado, pois não permitia ao imputado participar pessoalmente do julgamento, nem repensar a própria defesa e pedir, se fosse o caso, a assunção de novas provas.

A Corte de Cassação afastou facilmente a impugnação, com base em uma radicada orientação jurisprudencial, segundo a qual não existe violação do direito ao contraditório quando o imputado tenha tido possibilidade de contraditar a nova qualificação jurídica por meio do remédio da impugnação perante o juiz de legitimidade ${ }^{22}$. Afirmou-se que, em relação ao caso concreto examinado, com a reabertura do julgamento e a realização de uma nova audiência diante da corte, já havia sido permitido à parte contraditar a questão jurídica, e a parte também havia sido especificamente informada sobre a nova qualificação jurídica do fato, tendo assim tempo para preparar a própria defesa e apresentá-la em contraditório no órgão de acusação.

Isso, na verdade, seria suficiente a restaurar o status anterior à violação encontrada pela Corte de Estrasburgo, em plena conformidade com o art. 41 CEDH que, como é notório, determina que a consequência primária do reconhecimento de uma violação à norma convencional é a reabertura do procedimento, com a reparação dos efeitos prejudiciais do trânsito em julgado. Dito em outros termos, a sentença do TEDH afirma, no caso Drassich, que a violação convencional ocorreu com modificação-surpresa do crime contestado, não supondo minimamente uma contestação fática da diferente qualificação jurídica. Segue-se que, em falta de alterações do julgamento sobre o fato, visto que o vício processual se consumou durante o julgamento da cassação, e não em sede de mérito, deve a mesma corte remediá-lo.

A decisão tem que se considerar compartilhável. De fato, neste caso não se poderia nem sequer em abstrato supor que a reabertura do procedimento tivesse que se realizar retornando à fase de mérito, visto que os limites da revogação da decisão de cassação de 2004 se referiam exclusivamente à distinta qualificação jurídica do fato, não tocando minimamente na essência do conteúdo da acusação. Deixando firme a identidade dos elementos fáticos, e considerando o dever do órgão jurisdicional de subsumir em via definitiva a fattispecie concreta naquela abstrata que considera mais justa ${ }^{23}$, no caso objeto de análise o diferente enquadramento jurídico do fato reentra no grupo

\footnotetext{
${ }^{22}$ Entre muitas, ver Corte di Cassazione penale, Seção II, 13 novembro 2012, número 45.795, em Diritto e giustizia on line, 26 de novembro de 2012; contra, porém, Corte di Cassazione, Seção V, 28 de outubro de 2011, número 6.487 em C.E.D. Cassazione, n. 251730, a qual considera configurável uma nulidade em seguida ao diferente nomen iuris atribuído aos fatos na sentença, sem o prévio contraditório. Todavia, tal decisão se refere a hipóteses de requalificações operadas em sede de mérito e não em sede de legitimidade: segue-se que a anulação com reenvio por parte da Cassazione tinha a evidente intenção de trazer o processo ao ponto em que foi verificada a invalidade processual.

${ }^{23}$ Assim Corte di Cassazione penale, Seção II, 24 de setembro de 2012, número 7.984.
} 
de uma limitadíssima gama de previsões alternativas; portanto, a eventual exclusão de um traz inevitavelmente a aplicação do outro ${ }^{24}$.

Por outro lado, em tema de exercício do poder do juiz de atribuir ao fato uma definição jurídica diferente, uma leitura constitucionalmente e convencionalmente orientada do artigo 521, parágrafo 1 do CPP italiano requer somente a exigência de que a distinta qualificação não aconteça de surpresa e com prejuízo para o direito de defesa do imputado ${ }^{25}$. Portanto, tal pré-requisito pode-se considerar atendido se o réu tiver a possibilidade de contraditar preventivamente sobre o conteúdo da acusação, até mesmo por meio de eventual rediscussão in iure, desde que, naturalmente, a modificação do nomen iuris não envolva a referência a uma fattispecie estruturalmente não homogênea em relação ao episódio concreto objeto do processo. Nessa perspectiva, o princípio da correlação constitui uma garantia para o imputado, o qual é protegido do risco de ser julgado por fatos que não foram formalmente informados e, portanto, de ver danificada a defesa apresentada em relação às acusações iniciais. Segue-se, em caso de inobservância da obrigação do contraditório preventivo à requalificação, um vício processual denunciável ex art. 606 do CPP italiano ${ }^{26}$.

Resulta-se, portanto, neste caso, um julgamento com plena observância do inédito mecanismo ex art. 625-bis do CPP italiano aos objetivos reparadores genericamente colocados pelo TEDH: em relação ao conteúdo restitutório que a reabertura do procedimento teria que garantir ao recorrente segundo os juízes de Estrasburgo, com a reabertura do processo já se teria adotado a necessária iniciativa e já se teria alcançado a restitutio in integrum idônea a restaurar as garantias violadas, visto que, no caso específico, não se tratava de corrigir o êxito do julgamento do fato, mas somente de devolver ao recorrente as chances processuais perdidas em razão da ofensa trazida ao seu direito de defesa. Em termos idênticos, além disso, posicionou-se a Corte Constitucional italiana, afirmando que com a nova revisão europeia o objetivo perseguido não seria remediar uma apreciação defeituosa do fato por parte do juiz, mas devolver ao destinatário a situação equivalente àquela na qual ele teria se encontrado em ausência da violação reconhecida.

\footnotetext{
${ }^{24}$ Entre muitas, ver Cassazione penale, Seção VI, 4 de fevereiro de 2004, número 23.024.

${ }^{25}$ Assim, Cassazione penale, Seção V, 24 de setembro de 2012, número 7.984.

${ }^{26}$ A referência é ao recurso de cassação, para o qual o art. 606 do CPP italiano oferece um elenco taxativo dos motivos pelos quais é possível apresentá-lo.
} 


\subsection{A REVISÃO EUROPEIA NO CASO DRASSICH EM FACE À SENTENÇA CONSTITUCIONAL}

Foi dito como a sentença em exame teria constituído a ocasião, para a Suprema Corte, de efetuar uma reconstrução das passagens-chave da já lembrada sentença da corte constitucional número 113 de 2001, na tentativa de individualizar a exata dimensão das condições necessárias para instaurar o peculiar julgamento de revisão europeia, considerando a ausência de uma disciplina orgânica em tema de reabertura do procedimento em presença de graves violações do direito de defesa que foram realizadas durante o processo que resultou na sentença irrevogável.

O ponto de partida do raciocínio é o art. 46 da CEDH, por força do qual, convém lembrar, cada Estado parte “se empenha a conformar-se às sentenças” da Corte Europeia (SACCUCCI, 2002, p. 618 et seq.). Os respectivos países, portanto, são obrigados a implementar as consequências jurídicas das decisões do TEDH, por meio da adoção de medidas internas.

Como é notório, é tarefa do país condenado, depois de ter conhecimento da sentença europeia, dar execução com instrumentos jurídicos adequados. Tanto que, sempre sobre o tema de execução das sentenças, o art. 41 da CEDH reconhece que "se a Corte declara que existe violação da Convenção ou dos seus protocolos e se o direito interno da Alta parte contraente não permite a não ser em modo incompleto reparar as consequências da violação, a Corte estabelece, quando é o caso, uma satisfação equitativa à parte lesada”. O reconhecimento de reparação pecuniária, segundo previsto na norma, portanto, tem natureza subsidiária e se associa ao pressuposto de que, do ponto de vista jurídico, o ordenamento nacional não possa remediar a violação.

Concentrando-se sobre o dado literal, conforme posição majoritária, nota-se que as sentenças do TEDH têm natureza meramente declarativa. Com essas, uma violação da Carta dos direitos fundamentais e as consequências da condenação ao ordenamento interno não são diretamente inerentes às sentenças europeias, mas remetidas à decisão do Estado-parte. Vice-versa, subsiste diante desse uma obrigação de ativação para garantir às vítimas a restitutio in integrum, isto é, um dever de adoção de medidas aptas a recriar a situação antecedente à violação da norma convencional.

Ao mesmo tempo, o Conselho dos Ministros é o órgão do sistema chamado a verificar se os respectivos países cumprem as obrigações estabelecidas nas sentenças do TEDH: em atuação sob o art. 46 da CEDH, o Conselho começou a emitir juízos rigorosos, sobretudo em tema de reabertura, reconhecendo que, em presença de certos pré-requisitos, o Estado não pode invocar a intangibilidade do trânsito em julgado como motivo idôneo a exonerá-lo das próprias obrigações ${ }^{27}$.

\footnotetext{
${ }^{27}$ Veja-se, por exemplo, ZWAAK, 2006, p. 296 et seq.
} 
A partir dessas premissas conceituais, portanto, deve-se reler a afirmação da Corte Constitucional italiana, segundo a qual se deve proceder à reabertura do processo quando isso for necessário aos sentidos do art. 46 da CEDH, tendo em mente a complexidade que se esconde por trás de tal obrigação. De fato, em razão do quadro delineado, a aplicabilidade das disposições normativas ditadas na temática da revisão não parece fácil. Assim, com referência específica à sentença em exame no caso Drassich, tal consideração talvez devesse levar a Corte de Cassação a um passo subsequente, até então não efetuado nem nesse, nem em outros casos; ou seja, a perguntar-se mais a fundo sobre o significado que se deve atribuir à afirmação da Corte Constitucional segundo a qual a revisão ex art. 630 do CPP italiano seria funcional à detecção de um instrumento para assegurar a reabertura do processo de mérito.

É necessário lembrar, de fato, que a reabertura opera somente depois que tenha se formado legitimamente a coisa julgada nacional, e que essa renovação se fundamenta sobre a obrigação de respeitar um vínculo internacional de proteção dos direitos humanos. O direito à renovação do processo, que supera o princípio de intangibilidade da coisa julgada e, com esse, a soberania nacional, segundo a Corte Constitucional, pode entrar no sistema italiano porque é imposto por um sistema internacional.

\section{A REVISÃO CRIMINAL NA JUSTIÇA CRIMINAL BRASILEIRA E A AUSÊNCIA DE PREVISÃO EXPRESSA PARA OS CASOS DE REABERTURA DO PROCESSO POR CONDENAÇÕES EM SENTENÇAS DOS TRIBUNAIS INTERNACIONAIS}

A partir das considerações expostas nos tópicos anteriores, especialmente no item 1.2, e desvelada a sua complexidade a partir do exemplo italiano, assentam-se três conclusões parciais: 1) os Estados-parte têm dever de respeitar e cumprir as decisões das cortes internacionais de direitos humanos a que tenham se submetido - especialmente quando condenados, em processos que tenham atuado como parte, por violações às regras convencionais do devido processo penal; 2) embora não de modo indiscriminado em todos os casos, em diversas situações será necessária a reabertura do processo, com o rompimento da coisa julgada interna, de modo a possibilitar a reparação da violação cometida e afastar a condenação penal convencionalmente ilegítima; e, 3) diante da ausência de força executiva direta, em relação ao âmbito interno dos Estados-partes, das decisões das cortes internacionais, é indispensável a existência de mecanismo jurídico internamente previsto para 
possibilitar a efetividade das decisões internacionais, com a possibilidade de seu requerimento por iniciativa do imputado (vítima da violação à norma convencional).

Considerando tais premissas, deve-se analisar o cenário brasileiro atual, questionando-se: Como assegurar efetividade às decisões da Corte IDH em casos de condenação do Brasil por haver proferido sentença condenatória definitiva convencionalmente ilegítima em razão de violação à regra do devido processo penal prevista na CADH? Para examinar tal problemática, partir-se-á da inexistência de previsão legal expressa para, então, propor-se reforma legislativa futura, ressaltandose que desde já, enquanto inalterado o quadro legislativo, dever-se-ia utilizar mecanismo cabível de interpretação extensiva.

Primeiramente, é fundamental distinguir entre as sentenças estrangeiras e as internacionais. Conforme o ordenamento pátrio, as decisões emitidas por autoridades judiciais de países estrangeiros devem ser homologadas pelo Poder Judiciário brasileiro, para somente assim obterem eficácia interna. Nos termos do art. 105, I, “i”, da CF, o procedimento de homologação de sentença estrangeira é realizado pelo Superior Tribunal de Justiça (STJ). Contudo, as decisões de tribunais internacionais de direitos humanos têm natureza distinta, pois, ao não se vincularem à soberania de nenhum Estado, são denominadas sentenças internacionais (PEREIRA, 2013a, p. 104). Diante disso, a doutrina majoritária afirma que “a homologação de sentença estrangeira prevista no artigo 105, I, 'i', da Constituição não se aplica às sentenças da Corte Interamericana de Direitos Humanos” (RAMOS, 2008, p. 459) ${ }^{28}$.

No sistema brasileiro, o instrumento mais adequado para assegurar efetividade às decisões internacionais é a revisão criminal ${ }^{29}$. Como apontado anteriormente, o acesso às cortes internacionais, em regra, é autorizado somente após o exaurimento dos meios jurídicos internos, de modo que haverá o trânsito em julgado da condenação proferida pelo Judiciário brasileiro. Assim, para o rompimento da coisa julgada impõe-se o ingresso da revisão criminal (RANGEL, 2012, p. 266-267). Essa é a tendência também no panorama internacional, pois a revisão “tem sido a via processual mais utilizada por particulares para tentar assegurar a eficácia internas das sentenças do TEDH, pois se trata de uma ação autônoma de impugnação que pode deixar sem efeito um estado jurídico determinado, abrindo assim a possibilidade de um novo juízo” (MONTESINOS PADILLA, 2016, p. 105, tradução nossa).

\footnotetext{
${ }^{28}$ Assim também: CAMPOS, 2014, p. 77; LEITE, 2008, p. 449-452; RESENDE, 2013, p. 233; SANTOS, 2011 , p. 286.

${ }^{29}$ Por limitações de espaço e para evitar fuga do objeto central da pesquisa, este trabalho não aprofundará o estudo das demais opções de mecanismos para internalizar as condenações das cortes internacionais. Sobre isso, no exemplo italiano, ver GIALUZ, 2009, p. 1.844.
} 
De modo distinto do habeas corpus, que, em tese, poderia ser cabível em casos extremos e manifestos, a efetivação da sentença internacional proferida pela Corte IDH necessita de maior aprofundamento cognitivo no caso penal anteriormente julgado, em muitas situações pressupondo a análise probatória e de mérito. Portanto, como regra, em tal situação é cabível a revisão criminal, embora não se possa afastar incondicionalmente a possibilidade de impetração de habeas corpus em casos excepcionais, em que a ilegalidade seja manifesta em razão da violação reconhecida pelo tribunal internacional.

Analisando-se o cenário normativo brasileiro, percebe-se que, conforme o art. 621 do CPP, a revisão criminal é admissível quando: 1) a sentença condenatória for contrária ao texto expresso da lei penal ou à evidência dos autos; 2) a sentença condenatória se fundar em depoimentos, exames ou documentos comprovadamente falsos; e, 3) após a sentença, se descobrirem novas provas de inocência do condenado ou de circunstância que determine ou autorize diminuição especial da pena. Assim, não há previsão expressa de cabimento nos casos de condenação proferida contra o Brasil pela Corte IDH, o que enseja, desde já, a necessidade de alteração legislativa.

Contudo, até que sobrevenha novo diploma normativo, não se pode aceitar a inexistência de mecanismo jurídico interno a assegurar efetividade aos julgados internacionais. Caso contrário, estarse-ia incorrendo em nova violação convencional, pois o art. 25.1 da CADH prevê que

Toda pessoa tem direito a um recurso simples e rápido ou a qualquer outro recurso efetivo, perante os juízes ou tribunais competentes, que a proteja contra atos que violem seus direitos fundamentais reconhecidos pela Constituição, pela lei ou pela presente Convenção, mesmo quando tal violação seja cometida por pessoas que estejam atuando no exercício de suas funções oficiais.

Afirma-se que, embora a revisão criminal tenha sua aplicabilidade regulada em lei, “o rol taxativo de hipóteses da revisão não tem impedido a sua utilização por quem teve seus direitos violados por atuação judicial, quando essa vulneração tenha sido reconhecida pelo TEDH” (MONTESINOS PADILLA, 2016, p. 105, tradução nossa). Diante disso, no ordenamento brasileiro, pensa-se que é possível a interpretação extensiva da hipótese prevista no inciso III do art. 621 do CPP, considerando que a condenação proferida pela Corte Interamericana de Direitos Humanos é uma circunstância que pode determinar a absolvição ou a diminuição da pena do imputado, tendo em vista a violação à norma convencional reconhecida.

Resta claro que um Estado-parte, que é signatário do diploma internacional de proteção aos direitos humanos e se submeteu à jurisdição de corte internacional, não pode alegar a existência ou ausência de normas em seu ordenamento interno para justificar um descumprimento aos preceitos convencionais ou às decisões internacionais em que tenha sido condenado (CAMPOS, 2014, p. 80). 
Isso, inclusive, é expressamente regulado no art. 27 da Convenção de Viena sobre o Direito dos Tratados, de 1969 (RESENDE, 2013, p. 233). Ou seja, “não é pelo fato de no Brasil não existir um mecanismo próprio de execução das sentenças da Corte Interamericana que ele poderá descumprir a sentença em que for condenado” (LEITE, 2008, p. 448). Certamente, há e haverá resistência dos atores jurídicos nacionais, diante do impacto limitativo aos seus poderes ocasionado pela ampliação da força dos julgados dos tribunais internacionais (AMODIO, 2003, p. 85), o que provavelmente reforça o argumento de fragilização da soberania brasileira. Contudo, a força normativa da proteção internacional dos direitos humanos não pode ser limitada por obstáculos previstos no ordenamento interno dos Estados signatários das convenções.

Entretanto, a admissibilidade por interpretação extensiva deve ser uma "alternativa provisória”, visto que se impõe a alteração normativa para inserção de hipótese de cabimento específica no rol da revisão criminal. Afirma-se que "a inclusão de um motivo expresso para a revisão de processos internos em resposta a uma sentença condenatória proferida pelo TEDH é, em conclusão, se não imprescindível, ao menos conveniente” (MONTESINOS PADILLA, 2016, p. 107, tradução nossa). Impõe-se, portanto, a criação de denominada "lei-ponte” (CAMPOS, 2014, p. 82), ou "legislações nacionais de implementação das decisões de instâncias internacionais de proteção de direitos humanos” (RAMOS, 2008, p. 463).

Nessa discussão, a descrição do exemplo espanhol pode aportar contribuições. Enquanto inexistia previsão legislativa, diversos mecanismos eram utilizados para tentar assegurar a internalização das decisões do TEDH. Em um primeiro momento, foi aceita a utilização do recurso de amparo, o que posteriormente restou rechaçado, sob pena de desvirtuação de sua essência (MONTESINOS PADILLA, 2016, p. 104). Já a revisão criminal era aceita em certos casos (como na STC 96/2001), embora o Tribunal Supremo (TS) espanhol tenha apresentado certas restrições em acolher uma interpretação extensiva de "fato novo" para abarcar a sentença condenatória do TEDH (MONTESINOS PADILLA, 2016, p. 106). Recentemente, em outubro de 2014, a Sala do Penal do TS emitiu um acordo jurisprudencial, afirmando que, enquanto não existisse no ordenamento uma previsão legal para determinar a efetividade interna das sentenças internacionais, seria aplicável o art. 954 da Ley de Enjuiciamiento Criminal (LECrim), que regula a revisão criminal ${ }^{30}$.

Diante da pressão exercida pelo Judiciário ao Legislativo espanhol, em 2015 duas alterações normativas trataram da temática. Primeiro, a Ley Orgánica 7/2015, que alterou a Ley Orgánica del Poder Judicial ao inserir uma nova previsão, assentando que:

\footnotetext{
${ }^{30}$ Disponível em: <https://goo.gl/trax7m>. Acesso em: 17 set. 2017.
} 
Se podrá interponer recurso de revisión ante el Tribunal Supremo contra una resolución judicial firme, con arreglo a las normas procesales de cada orden jurisdiccional, cuando el Tribunal Europeo de Derechos Humanos haya declarado que dicha resolución ha sido dictada en violación de alguno de los derechos reconocidos en el Convenio Europeo para la Protección de los Derechos Humanos y Libertades Fundamentales y sus Protocolos, siempre que la violación, por su naturaleza y gravedad, entrañe efectos que persistan y no puedan cesar de ningún otro modo que no sea mediante esta revisión.

Em seguida, a Ley Orgánica 41/2015 introduziu a nova hipótese de cabimento da revisão criminal na LECrim, acrescentando ao art. 954 o seguinte dispositivo:

\begin{abstract}
3. Se podrá solicitar la revisión de una resolución judicial firme cuando el Tribunal Europeo de Derechos Humanos haya declarado que dicha resolución fue dictada en violación de alguno de los derechos reconocidos en el Convenio Europeo para la Protección de los Derechos Humanos y Libertades Fundamentales y sus Protocolos, siempre que la violación, por su naturaleza y gravedad, entrañe efectos que persistan y no puedan cesar de ningún otro modo que no sea mediante esta revisión. En este supuesto, la revisión sólo podrá ser solicitada por quien, estando legitimado para interponer este recurso, hubiera sido demandante ante el Tribunal Europeo de Derechos Humanos. La solicitud deberá formularse en el plazo de un año desde que adquiera firmeza la sentencia del referido Tribunal.
\end{abstract}

De modo mais abrangente, o Comitê de Especialistas na Reforma da Corte (DH-GDR), vinculado ao TEDH, realizou pesquisa entre os membros do Conselho da Europa, verificando a possibilidade de reabertura interna de casos após o julgamento pelo tribunal internacional. Conforme o Relatório DH-GDR(2015)008 Rev., dos 46 Estados que responderam à pesquisa, 33 permitem a reabertura do caso penal, sendo que em 30 deles há previsão legal expressa de mecanismos que autorizam tal procedimento ${ }^{31}$.

Diante desse panorama, pensa-se que a legislação brasileira deve ser alterada, inserindo-se expressamente a "revisão criminal convencional", de modo a possibilitar a efetividade interna das decisões proferidas pela Corte Interamericana de Direitos Humanos com condenação ao Brasil por violação de norma convencional de proteção ao devido processo penal. Assim, inspirada no exemplo espanhol, propõe-se a seguinte redação:

Dá-se a seguinte redação ao artigo 621 do Decreto-Lei 3.689/41, “Código de Processo Penal” (ou ao artigo 655 do PL 8.045/10, que propõe um novo CPP):

Art. 621. A revisão dos processos findos será admitida:

[...]

IV - quando houver manifestação definitiva da Corte Interamericana de Direitos Humanos declarando que a sentença foi proferida em processo com violação aos direitos e garantias previstos na Convenção Americana de Direitos Humanos, e sua reabertura for necessária à reparação do dano.

\footnotetext{
${ }^{31}$ Disponível em: <https://goo.gl/RR44q3>. Acesso em: 17 set. 2016.
} 
Nesses casos, a admissão da revisão criminal é necessária para verificar a amplitude da violação cometida e de suas consequências ao processo de um modo geral, analisando-se, por exemplo, a contaminação de atos subsequentes. Em regra, o reconhecimento da violação declarada pela corte internacional deverá ser respeitado pelo julgador pátrio (MIRANDA BURGOS, 2014, p. 133). Contudo, pode haver casos em que a reabertura integral do processo não se mostre obrigatória (KOSTORIS, 2009, p. 2.523 et seq.). Por exemplo, se houver a declaração da transgressão do direito a um julgador imparcial e natural (art. 8.1, CADH), todo o processo deverá ser anulado e, se não prescrito o crime, refeito. Por outro lado, em caso de violação ao direito à prova defensiva (art. 8.2.f, $\mathrm{CADH}$ ) ou ao recurso sobre a condenação (art. 8.2.h, CADH), aventa-se a nulidade dos atos do processo a partir do momento da violação, o que dependerá da análise do caso concreto.

De qualquer modo, é inadmissível aceitar que uma condenação criminal avessa aos ditames internacionais de proteção mínima aos direitos humanos, por violação à regra do devido processo penal, resista no ordenamento interno. Assim, não se deve questionar sobre a “justiça” do mérito da decisão, pois a “credibilidade objetiva do julgamento interno” restará fragilizada em razão da violação ocorrida durante o desenvolvimento do processo (GERACI, 2012, p. 82, tradução nossa), o que impõe a sua reabertura para eventual exclusão do ato defeituoso e verificação da possibilidade de sua renovação (GLOECKNER, 2013, p. 468-475).

\section{CONSIDERAÇÕES FINAIS}

Embora os casos julgados pela Corte IDH contra o Brasil ainda sejam pouco numerosos e não tenham relação com episódios de condenações ilegítimas por violações a regras convencionais do devido processo penal, há uma forte tendência de expansão da sua atuação, de modo semelhante ao ocorrido com o TEDH. E, quando essa expansão ocorrer, o ordenamento brasileiro deverá estar preparado para recepcionar e respeitar as decisões da Corte IDH, como medida de consolidação da proteção internacionais dos direitos humanos.

Diante disso, retoma-se ao problema que guiou este trabalho: Como assegurar a efetividade das decisões das cortes internacionais em casos de violações a regras convencionais do devido processo penal que reconheçam a injustiça de uma condenação criminal proferida em âmbito interno e transitada em julgado?

1. O Brasil, por ser signatário da $\mathrm{CADH}$, deve adequar seu ordenamento jurídico às normas convencionais nela previstas, além de buscar a conformidade da atuação de todos os seus Poderes, inclusive o Judiciário, a tais ditames. Nesse sentido, além de realizar um “controle difuso de 
convencionalidade”, os tribunais brasileiros devem respeitar as decisões da Corte IDH, especialmente nos casos em que o País figurar como parte e ocorrer o reconhecimento de violação a direito humano convencionalmente previsto.

2. Portanto, é necessário introduzir mecanismos jurídicos para assegurar a efetividade das decisões da Corte IDH internamente no ordenamento brasileiro, abrangendo suas diversas consequências para garantir a reparação do dano causado, tanto por medidas de responsabilização pecuniária, como em modificações normativas ou na alteração da situação de violação de um modo amplo.

3. Em casos de condenações criminais ilegítimas, em razão de violação à norma convencional do devido processo penal, em diversas circunstâncias o único modo possível para a reparação é a reabertura do caso penal, com o rompimento da coisa julgada condenatória interna, de modo a possibilitar a revisão da sentença proferida anteriormente e considerada ilegítima pela Corte $\mathrm{IDH}^{32}$.

4. Desse modo, o instrumento adequado para assegurar a efetividade das decisões internacionais proferidas pela Corte IDH nos casos de violação de norma convencional do devido processo penal é a revisão criminal, visto que se trata de mecanismo apto a romper com a coisa julgada, a partir do reexame do caso penal de um modo amplo.

5. Diante do exposto, é necessário alterar a legislação brasileira, de modo a introduzir hipótese expressa nesse sentido no rol de cabimento da revisão criminal, conforme proposta de redação sugerida neste trabalho. Enquanto houver inércia legislativa, deve-se admitir a interpretação extensiva do inciso III do art. 621 do CPP, considerando que a condenação proferida pela Corte Interamericana de Direitos Humanos é uma circunstância que pode determinar a absolvição ou a diminuição da pena do imputado, tendo em vista a violação à norma convencional reconhecida.

A partir da realização prática da tese proposta neste trabalho, quando houver condenações do Brasil na Corte IDH por violações a regras convencionais do devido processo penal e for admitido ingresso da revisão criminal para sua efetivação interna, diversas questões surgirão, impondo maiores aprofundamentos no estudo em futuras pesquisas. A tese aqui sustentada, portanto, fomentará a

\footnotetext{
${ }^{32}$ É importante ressaltar que as teses aqui sustentadas se direcionam aos casos em que uma condenação proferida em processo penal no Estado-parte é considerada ilegítima pela Corte IDH, em razão de violação à norma convencional do devido processo legal. Situação distinta ocorre nas hipóteses em que se reconhece a insuficiência da investigação e da persecução penal interna, com a determinação de adoção de medidas para assegurar maior investigação dos fatos e eventual punição de responsáveis (como ocorrido em processos nos quais o Brasil já foi condenado pela Corte IDH - por exemplo, nos casos Escher, Garibaldi, Gomes Lund e Ximenes Lopes). Pensa-se que tais situações envolvem complexidades e premissas distintas, de modo que a visão sustentada neste trabalho não pode ser transplantada acriticamente, demandando análises mais aprofundadas.
} 
consolidação da proteção internacional dos direitos humanos e a força do sistema interamericano, além de contribuir para o fortalecimento do processo penal como instrumento de limitação do poder punitivo estatal (VASCONCELLOS, 2016, p. 192-194).

\section{REFERÊNCIAS}

AMODIO, Ennio. Processo penale, diritto europeo e common law. Dal rito inquisitorio al giusto processo. Milano: Giuffrè, 2003.

ANDRADE, Isabela Piacentini de. A execução das sentenças da Corte Interamericana de Direitos Humanos. Revista Brasileira de Direito Internacional, Curitiba, v. 3, n. 3, p. 147-162, jan./jun. 2006. DOI: <https://doi.org/10.5380/rbdi.v3i3.6566>.

BADARÓ, Gustavo Henrique. Processo penal. 2. ed. Rio de Janeiro: Elsevier, 2014.

BARROSO, Luís Roberto. Constituição e tratados internacionais: alguns aspectos da relação entre direito internacional e direito interno. In: MARINONI, Luiz G.; MAZZUOLI, Valerio de O. (Coord.). Controle de convencionalidade. Brasília: Gazeta Jurídica, 2013.

CAIANIELLO, Michele. La riapertura del processo ex art. 625-bis c.p.p. a seguito di condanna della Corte europea dei diritti dell’uomo. Cassazione penale, v. 4, p. 1.465-1.473, 2009.

CAIANIELLO, Michele. Mutamento del nomen iuris e diritto a conoscere la natura e i motivi dell'accusa $e x$ art. 6 C.e.d.u.: le possibili ripercussioni sul sistema italiano. Giustizia penale, p. 165176, 2007.

CAIANIELLO, Michele. Premesse per una teoria del pregiudizio effettivo nelle invalidità processuali penali. Bologna: Bononia, 2012.

CAMPOS, Bárbara P. C. A trajetória da implementação de sentenças da Corte Interamericana de Direitos Humanos no Brasil. Revista do Instituto Brasileiro de Direitos Humanos, v. 14, n. 14, p. 75-88, 2014.

CAPPARELLI, Bruna. Decisioni della corte europea e giudicato penale "iniquo". Revista Brasileira de Direito Processual Penal, Porto Alegre, v. 2, p. 241-268, 2016. DOI: $<$ https://doi.org/10.22197/rbdpp.v2i1.23>.

CAPPARELLI, Bruna; VASCONCELLOS, Vinicius G. A decisão da Corte constitucional italiana no "caso Eternit-bis": questões novas sobre as relações entre bis in idem processual e concurso formal de crimes? Revista de Estudos Criminais, Porto Alegre, 2018, no prelo.

CAPRIOLI, Francesco. Giudicato e pena illegale: riflessioni a margine di una recente sentenza della Corte costituzionale. In: BARGIS, Marta (Org). Studi in ricordo di Maria Gabriella Aimonetto. Milano: Giuffrè, 2013, p. 263-292.

CAPRIOLI, Francesco; VICOLI, Daniele. Procedura penale dell'esecuzione. Torino: Giappichelli, 2011. 
CEIA, Eleonora Mesquita. A jurisprudência da Corte Interamericana de Direitos Humanos e o desenvolvimento da proteção dos direitos humanos no Brasil. Revista EMERJ, Rio de Janeiro, v. 16, n. 61, p. 113-152, jan.-fev. 2013.

CHOUKR, Fauzi H. Diálogos possíveis entre o Supremo Tribunal Federal e a Corte Interamericana de Direitos Humanos no "Caso Araguaia": uma defesa ampla, geral e irrestrita dos direitos humanos? Revista Brasileira de Direito Processual Penal, Porto Alegre, v. 2, p. 269-299, 2016.

CORAO, Carlos M. Ayala. La ejecución de sentencias de la Corte Interamericana de Derechos Humanos. Estudios Constitucionales, ano 5, n. 1, p. 127-201, 2007.

CUNHA, J. S. Fagundes; BALUTA, José Jairo. O processo penal à luz do Pacto de São José da Costa Rica. Curitiba: Juruá, 2000.

GERACI, Rosa Maria. Sentenze dela corte e.d.u. e revisione del processo penale. Roma: Dike, 2012.

GIACOMOLLI, Nereu J. O devido processo penal. Abordagem conforme a Constituição Federal e o Pacto de São José da Costa Rica. São Paulo: Atlas, 2014.

GIALUZ, Mitja. Il riesame del processo a seguito di condanna della Corte di Strasburgo: modelli europei e prospettive italiane. Rivista italiana di diritto e procedura penale, n. 4, p. 1.844-1.895, 2009.

GLOECKNER, Ricardo Jacobsen. Nulidades no processo penal: introdução principiológica à teoria do ato processual irregular. Salvador: JusPodivm, 2013.

GLOECKNER, Ricardo Jacobsen. Três teses sobre a inconstitucionalidade substancial do art. 383 do CPP: por que o réu não se defende (apenas) dos fatos. Revista Brasileira de Direito Processual Penal, Porto Alegre, v. 2, p. 185-212, 2016. DOI: <https://doi.org/10.22197/rbdpp.v2i1.21>.

KOSTORIS, Roberto E. (Org.). Manuale di procedura penale europea. Milano: Giuffrè, 2014.

KOSTORIS, Roberto E. Diversa qualificazione giuridica del fatto in Cassazione e obbligo di conformarsi alle decisioni della Corte europea dei diritti dell'uomo: considerazioni sul caso Drassich. Giurisprudenza italiana, p. 2.514-2.525, nov. 2009.

LEITE, Rodrigo de Almeida. As sentenças da Corte Interamericana de Direitos Humanos e a Execução no Brasil. Revista da ESMARN, Mossoró, v. 8, n. 1, p. 441-468, jan./jun. 2008.

MAC-GREGOR, Eduardo Ferrer; MÖLLER, Carlos María Pelayo. La obligación de 'respetar' y 'garantizar' los derechos humanos a la luz de la jurisprudencia de la Corte Interamericana. Estudios Constitucionales, ano 10, n. 2, p. 141-192, 2012. DOI: <https://doi.org/10.4067/s0718$52002012000200004>$.

MAUÉS, Antonio Moreira. Supralegalidade dos tratados internacionais de direitos humanos e interpretação constitucional. SUR: Revista Internacional de Direitos Humanos, São Paulo, v. 10, n. 18, p. 214-235, jun. 2013. 
MAZZUOLI, Valerio de Oliveira. O Controle jurisdicional da convencionalidade das leis. 3. ed. São Paulo: RT, 2013.

MENDES, Gilmar Ferreira. A supralegalidade dos tratados internacionais de direitos humanos e a prisão civil do depositário infiel no Brasil. In: MARINONI, Luiz G.; MAZZUOLI, Valerio de O. (Coord.). Controle de convencionalidade. Brasília: Gazeta Jurídica, 2013.

MIRANDA BURGOS, Marcos José. La ejecución de sentencias de la Corte Interamericana de Derechos Humanos en el ordenamiento jurídico interno. Revista do Instituto Interamericano de Derechos Humanos, v. 60, p. 129-156, 2014.

MONTESINOS PADILLA, Carmen. El recurso de revisión como cauce de ejecución de las sentencias del Tribunal de Estrasburgo: pasado, presente y futuro. Eunomía - Revista en Cultura de la Legalidad, n. 10, p. 98-113, abr./set. 2016.

ORLANDI, Renzo. L’attività argomentativa delle parti nel dibattimento penale. In: FERRUA, Paolo et al. (Org.). La prova nel dibattimento penale. 4. ed. Torino: Giappichelli, 2010, p. 3-74.

PEREIRA, Luciano Meneguetti. A execução das sentenças da Corte Interamericana de Direitos Humanos no Brasil. In: SILVEIRA, Daniel Barile da (Org.). A Corte Interamericana de Direitos Humanos e sua jurisprudência. Birigui: Unitoledo, 2013a.

PEREIRA, Taís Mariana Lima. O cumprimento das decisões da Corte Interamericana de Direitos Humanos pelo Brasil. Espaço Jurídico Journal of Law, v. 13, n. 2, p. 315-348, 2013b.

PIOVESAN, Flávia. Direitos humanos e o direito constitucional internacional. 9. ed. São Paulo: Saraiva, 2009.

PIOVESAN, Flávia. Tratados internacionais de proteção dos direitos humanos e a Constituição Federal de 1988. Boletim IBCCRIM, São Paulo, n. 153, agosto/2005.

QUATTROCOLO, Serena. Riqualificazione del fatto: una parola, ma non conclusiva, della Corte Costituzionale. Legislazione penale, p. 337-344, 2010.

RAMOS, André de Carvalho. A execução das sentenças da Corte Interamericana de Direitos Humanos no Brasil. In: CASELLA, Paulo Borba et al. (Org). Direito internacional, humanismo e globalidade. São Paulo: Atlas, 2008, p. 451-468.

RAMOS, André de Carvalho. Teoria geral dos direitos humanos na ordem internacional. 4. ed. São Paulo: Saraiva, 2014.

RANGEL HERNÁNDEZ, Laura. Sentencias condenatorias al Estado mexicano dictadas por la Corte Interamericana de Derechos Humanos y sus implicaciones en el orden jurídico nacional. Revista del Instituto de Ciencias Jurídicas de Puebla, ano V, n. 28, p. 160-186, 2011.

RANGEL, Paulo. A coisa julgada no processo penal brasileiro como instrumento de garantia. São Paulo: Atlas, 2012. 
RESENDE, Augusto César Leite de. A executividade das sentenças da Corte Interamericana de Direitos Humanos no Brasil. Revista de Direito Internacional, Brasília, v. 10, n. 2, p. 225-236, 2013. DOI: <https://doi.org/10.5102/rdi.v10i2.2579>.

RUIZ MIGUEL, Carlos. La STEDH sobre la doctrina Parot y el problema de la ejecución de las sentencias del TEDH. In: MÍNGUEZ ROSIQUE, M. (Coord.); PÉREZ MANZANO, M.; LASCURAÍN SÁNCHEZ, J. A. (Dir.). La tutela multinivel del principio de legalidad penal. Madrid: Marcial Pons, 2016, p. 377-408.

SACCUCCI, Andrea. Obblighi di riparazione e revisione dei processi nella convenzione europea dei diritti dell'uomo. Rivista di diritto internazionale, v. 3, p. 618-681, 2002.

SANTOS, Juliana Corbacho N. A execução das decisões emanadas da Corte interamericana de direitos humanos e do sistema jurídico brasileiro e seus efeitos. Prismas, Brasília, v. 8, n. 1, p. 261307, jan./jun. 2011. DOI: <https://doi.org/10.5102/prismas.v8i1.1327>.

STEFANO, Maurizio. Dopo la Corte di Strasburgo, la revisione del processo penale in Italia: una sentenza epocale della Corte costituzionale. I diritti dell'uomo, n. 1, p. 1-6, 2011.

UBERTIS, Giulio. L'adeguamento italiano alle condanne europee per violazioni dell'equità processuale. In: BALSAMO, Antonio; KOSTORIS, Roberto (Org.). Giurisprudenza europea e processo penale italiano. Torino: Giappichelli, 2008.

UBERTIS, Giulio. La revisione successiva a condanne della Corte di Strasburgo. In: Giur. cost., 2011, p. 1.543-1.545.

VASCONCELLOS, Vinicius G. Lide na justiça criminal? Sobre a importância do conflito de interesses entre as partes processuais e sua irrelevância para a necessidade do processo penal. Revista Brasileira de Ciências Criminais, São Paulo, ano 24, v. 119, p. 165-199, mar./abr. 2016.

VASCONCELLOS, Vinicius Gomes de. Duplo grau de jurisdição na justiça criminal: o direito ao recurso como possibilidade de questionamento da motivação da sentença condenatória. In: GIACOMOLLI, Nereu; VASCONCELLOS, Vinicius G. (Org.). Processo penal e garantias constitucionais. Estudos para um processo penal democrático. Rio de Janeiro: Lumen Juris, 2014, p. 219-255.

ZWAAK, Leo. The supervisory task of the commitee of ministers. In: VAN DIJK, Pieter et al. (Ed.). Theory and practice of the European convention on human rights. Oxford: Intersentia, 2006.

Vinicius Gomes de Vasconcellos Doutorando em Direito pela Universidade de São Paulo - USP (São Paulo, SP, Brasil), com período de sanduíche na Universidad Complutense de Madrid (Espanha) (bolsa PDSE/Capes). orcid.org/0000-0003-2020-5516. E-mail: vgomesv@gmail.com

Bruna Capparelli Doutoranda em Processo Penal pela Alma Mater Studiorum - Università di Bologna (Itália). orcid.org/0000-0003-1249-2658. E-mail: bruna.capparelli2@unibo.it 